\title{
Representation with/out Representation: Saudia Arabia as a Hidden Face of Globalization
}

\author{
Rüdiger Lohlker
}

The article discusses the European/North American concept of representation. It offers an alternative approach including the non-Western world. The case study discussed is the Kingdom of Saudi-Arabia and Wahhabism/Salafism.

Representation; Aerial Bombing; Saudi Arabia

Rüdiger Lohlker is professor of Islamic studies at the Oriental Institute, Vienna University. He has studied the phenomena of Jihadism and exclusivist Islam since the 1990s and published many books and articles in this field.

\section{Introduction}

Following debates about the crisis of representation makes somebody who is thinking about non-Western - if you allow me to cut a very complex discussion very short - ways of living in modern contexts feel uneasy. For us, it sounds like talking about "the crisis of liberal democracy" in the West ${ }^{1}-$ and leaving out the discussions about the 'rest' - still claiming the West as representing the universal situation. Esp., discussions like these tend to ignore the intimate relation of authoritarian regimes securing the survival of the liberal democracies and thus creating a global crisis.

We will argue in the following that the global crisis is just the cause of the backlash against liberal democracy supported by a global system that is not based on the principles of liberal democracy. The role of Saudi Arabia is the case study we will discuss. But let us turn at first to the idea of representation as understood in these lines.

1 Carl Raschke, Force of God: Political Theology and the Crisis of Liberal Democracy, New York/Chichester: Columbia University Press 2015. 


\title{
1. Critique of Representation
}

The concept of representation and its critique of Deleuze opens up new dimensions of thinking about representation, creates a new logic. As Henry SomersHall puts it:

\begin{abstract}
"[W]e saw how Deleuze attempts to introduce this concept of a difference that is not to be understood in terms of negation through the resort to new geometries, and in particular, geometries that are grounded in the differential calculus. In doing so, he attempted to provide us with a new logic, one that operates outside of the categories of representation" allowing "Deleuze to escape from the dialectical reduction of the beyond to appearance. Deleuze tries to achieve this through defining a third way between the two options that Hegel puts forward. On the one hand, difference is not the same as it is for immediate law, so it does not collapse into appearance immediately. On the other hand, it is not the difference of the inverted world, which is a difference taken to the level of opposition, so it is not open to reconciliation through contradiction. What defines this new approach, according to Deleuze, is that it proposes a new set of relations among the concepts of limitation, determination, and negation." ${ }^{2}$
\end{abstract}

Which way to follow to get out of the immanent problems of representation leaving "the categories of representation"? Following again Somers-Hall we may say:

"Deleuze $[\ldots]$ attempts to overturn the structure of judgment $[\ldots]$. Rather than reconceiving difference and identity through the infinitization of representation, Deleuze circumscribes a domain of representation, pure actuality, paralleling Kant's distinction between the phenomenal and the noumenal. Just as Kant shows that the notion of world cannot without be formulated, Deleuze shows that representational actuality requires the supplement of a non representational moment, the virtual. While the supplement in Kant's transcendental idealism is purely negatively determined, the noumenon as limit case, Deleuze develops a notion of virtuality that is positive and contentful. The limitations of judgment, therefore, point to the necessity of a moment that cannot be captured by the structure of judgment, just as Bergson's notion of intuition points to a nonspatial conception of time. Rather than extending representation to the point where it overcomes its limitations, Deleuze argues that totalized representation is a form of transcendental illusion, generated by a failure to analyze the genesis of the structure of judgment. Judgment is not merely incomplete, therefore, but is a false approach to the world, once it is severed from these genetic conditions. Without a recognition of a moment outside of representation, we are forced to conceive of difference in terms of the negation of a certain structure of judgment, for instance, rather than as a positive term in its own right. [...] It also allows us to explain why within finite representation there can be no specification of a principle of division: representation's genetic conditions are subrepresentational.

2 Henry Somers-Hall, Hegel, Deleuze, and the Critique of Representation. Dialectics of Negation and Difference, Albany, NY: SUNY Press 2012, p. 203. 
Deleuze's response to representation therefore also keeps in play both identity and difference. Rather than reconciling these two moments on the same ontological plane through a notion of contradiction, however, Deleuze separates difference and identity by making difference a transcendental condition of identity itself. Identity is grounded in the non-identical."3

According to Somers-Hall we may say that changing the plane of the transcendental illusion of totalized representation to the plane of immanence that is understood as a

"spatial flatnesss like that of a beach with its open horizon allowing Deleuze to coin the notion of the plane of immanence and refer it, esp., to Spinoza. Deleuze comes across this plane of immanence by the attempt to understand Spinoza from his center. Leaving the first and foremost principle of Spinoza aside he wants to turn to whole series of principles: There is one substance for all modi but beyond that there is only one nature for all individuals or bodies and this nature itself again is an individual in its continuous variation, a singular and collective body constantly transforming itself in infinite ways." ${ }^{4}$

This plane of immanence is "a plane of swarming difference and not full of difference." 5 Bearing this in mind, we may say, a way out of the problems of representation may be found in this Deleuzian understanding that prefers the turn to the nonidentical avoiding the creation of a position of judgement, subduing the other in a totalized representation, and leading to a hierarchical construction of the world.

Since the importance of the position of judgement in Deleuze may not be understood, some remarks are necessary. As Deleuze wrote in his book on Expressionism in Philosophy: Spinoza:

"It follows that nobody has the authority to decide my rights. Everyone in the state of nature, whether wise man or fool, judges what is good or bad, and what is necessary for his preservation. Whence natural right is not opposed 'to strifes, hatred, anger, treachery, or, in general, anything that appetite suggests.' And if comes about that we are lead to renounce our natural right, this will not happen through the recognition of the wise man's authority, but from our own consent to this authority, from fear of a greater evil or hope of a greater good." 6

3 Ibid., p. 242.

4 Christoph Dittrich, Weder Herr noch Knecht: Deleuzes Spinoza-Lektüren, Wien/ Berlin: Turia+Kant 2012, pp. 56-57.

5 Ibid.

6 Gilles Deleuze, Expressionism in Philosophy: Spinoza, New York: Zone Books 1990, p. 260; cf. ibid., pp. 258-259 for the context of a Hobbesian understanding of natural law. As a remark concerning the Saudi case study below: We have to stress that this understanding of Deleuzian concepts avoids the shortcomings of the reductionist reading 
The acceptance of the "wise man", the judge, means to leave the plane of immance and producing again the old idea of representation creating hierarchies and excluding non-European, non-civilized humans (see below). Only a new logic beyond this 'old' logic of representation (and, e. g., its Hegelian critique) will lead us out of the present impasse. ${ }^{7}$ Leaving the non-identical and non-representantional aside means an inability to understand the claim of Western representation as representing the universal as a claim of negating difference. This will lead to an ever-growing exclusion of humanity defined as non-European. Being non-European means being the object of violence in European wars and denied the hallowed principles of human rights understood as the core principles of liberal democracy. The crisis of liberal democracy means the disclosure of the real-life fundamentals of modern liberal democracy at a global level for the majority of humans globally, fundamentals that include non-representational powers (see below) acting as representatives of liberal representation. ${ }^{8}$

To understand the results of this exclusion of non-Europeans and them being subjected to violence we have to introduce another concept following a critical reading the 'old' logic of representation referring to a specific case study.

\section{Aerial Bombing, Democracy, and its Web of Preconditions}

Having said this, we would like to turn to an issue unlikely to be discussed in a context like this: aerial bombing. Talking about it may help us to conceptualize better the phenomena I want to talk about critically referring to Saudi Arabia and representation. The critical dimension of the rhizomatic conceptualization connecting these real-life facts is to be found in the Saudi bombs killing of thousands and thousands of Yemeni men and women. ${ }^{9}$ This is to be discussed in terms of

of Foucault by Said. We are not writing in the tradition of a critique of Orientalist or neoOrientalist positions. We are far beyond this very limited debate. The same holds true for any discussion of aspects of international law.

7 We may think, e.g., of an extraversion in the sense of Victor Segalen to conceptualize a European non-Eurocentric view added to a Deleuzian approach as a way out.

8 For those who are not able to understand: It is a play of words. We apologize for this infringement of etiquette of German academic style of writing.

9 We have to bear in mind that a war in Yemen was foreshadowing the decline of another power in the MENA region: Egypt (see W. Andrew Terrill, "The Chemical Warfare Legacy of the Yemen War”, in: Comparative Strategy 10ii (1991), pp. 109-119 and, e.g., Jesse Ferris, Nasser's Gamble: How the Intervention Caused the Six-Day-War and the Decline of Egyptian Power, Princeton, NJ: Princeton University Press 2013). For the recent war in Yemen (and against the Yemeni People) May Darwich, "Machtprestige als Motiv des saudischen Krieges im Jemen", in: GIGA focus nahost 6/2015, pp. 1-8, Zachary Laub, Yemen in Crisis, April 19, 2016; for the present situation see Holly Ellyatt, Saudi Arabia and Iran's Feud has entered a new 'unpredictable' phase. 
Rüdiger Lohlker

international law, but in the framework we developed before: the exclusion of humans from the liberal order of representation.

Why talking about aerial bombing as a phenomenon interrelated to representation this way? We have to approach in an unconventional manner: There is an important transition in the 19th century from personal/governmental wars to national wars; the "levée en masse" springs up to our mind.

In the laws of war, there are during the nineteenth century,

"two, partly contradictory, developments. On the one hand, the citizens are increasingly mobilized for military duties, and compulsory military service is being instituted. The armed forces and the nation, in other words, tend to merge. On the other hand, however, international law is being set up in order to protect non-combatant immunity, and thus to establish legally that unarmed civilians and armed combatants have to be treated differently. On the one hand, conscription tends to assimilate all citizens to the nation-state and its apparatus of violence, but, on the other hand, international law forbids private citizens being treated as representatives of their countries or states." ${ }^{10}$

The negation of representation mentioned by Hippler is the secret history of Western modernity. ${ }^{11}$ But:

"To the extent to which the limitation of warfare within Europe relied on the common ground of similar social organization and a shared civilization, the non-European 'others' were excluded from this habitual settlement and equally from codified international law. Hence, the practice of colonial war has always been very different from the limited forms of warfare that were, at least in principle, applied in Europe. Outside the European centre, the civilian populations have never been considered as having a right to protection from military action." 12

Deliberately targeting civilian populations was part and parcel of colonial warfare producing ideas that were later on used on European civilians. Targeting of civilians - who are not perceived as civilians - has a long history in colonial warfare. In his Small Wars: Their Principles and Practice, British Colonel C. E. Callwell wrote - quoting a South African ${ }^{13}$ experience - in $1896^{14}$ that a 'real war'

10 Thomas Hippler, Bombing the People: Giulio Douhet and the Foundation of Air Power Strategy, 1884-1939, Cambridge et al.: Cambridge University Press 2013, p. 11 seqq.

11 For those who are not able to understand: We are arguing at the plane of immanence (see above).

12 Ibid., p. 8.

13 South Africa is a case at hand when thinking about Africans and Afrikaners as people living in Africa and as such: non-Europeans and the British against them as paradigmatic colonial wars. 
"may be terminated by the surrender or capitulation of the hostile sovereign or chief, who answers for his people; but in the suppression of a rebellion the refractory subjects of the ruling power must all be chastised and subdued ... the main points of difference between small wars and regular campaigns ... are that, in the former, the beating of the hostile armies is not necessarily the main object even if they exist, that effect on morale is often far more important than material success, and that the operations are sometimes limited to committing havoc which the laws of regular warfare do not sanction."15

There is also a long history of attacking civilian population by naval attacks that have been taken over by the emerging airforces. ${ }^{16}$ After WW1 military theorists conceptualized attacks by aircrafts as the first wave of attacks in a new war. The people shaping these new strategies were deeply influenced by their experiences in colonial warfare. And is not surprising that the first aerial bombing was done by an Italian pilot fighting Arab/Muslims 'rebels' against Italian colonialism in 1911. At the same time the new air force was imagined, e.g., by the famous Italian theoretician of air wars, Giorgio Douhet, paradoxically a pacifist, as a means to end the wars, to control the enemies of a global peace among the - civilized - states - not the barbarous, uncivilized people everywhere else.

As we heard from Calwell, the decision is up to "the sovereign/chief," no representation is needed, it is only at the moral level that indirectly an indirect influence by his subjects may be exerted on "the sovereign/chief" to capitulate. The native population is constructed as an intermediary no laws of - civilized warfare applies to a group not to be represented or representing. So a civilized way of representation even if a ruler-subject structure is conceded to the people who are fought by the civilized armies in a non-civilized manner, but it is still a "subrepresentational" representation.

The dichotomy civilization vs. non-civilization exerts influence into European discussions after WW1 when another non-civilized enemy appeared in Europe: the working class uprising after the victory or defeat of the old powers conceived as endangering liberal democracy. In this case, the airpower theoreticians reflected upon the need to quell these uprisings by using airplanes in different ways, workers. Male and female, being seen as an un-civilized mass, a threat to civilization. As such they are amalgamated with the other non-civilized forces, the colonialized people fighting for their independence.

Another aspect: Thinking of the conscription as a process of assimilating the population into the nation-state, the distinction between representatives and represented disappears. The population becomes a legitimate target of aerial attacks as workforce supporting the military efforts, as supporters of the gov-

14 Charles E. Callwell, Small Wars: Their Principles and Practice, London: H.M.S.O $1906^{3}$.

15 Ibid., pp. 41-42.

16 See for this and the following remarks Hippler, Bombing. 
ernmental politics whose moral may be attacked to destroy their support, another way of putting "civilized" Europeans at the same level as "non-civilized" colonialized people. ${ }^{17}$

Colonial warfare creeps into European warfare, a bitter irony we may call it. Representation may be the wrong term to discuss these developments, or we might say representation is only applicable to people that are not subjected to European warfare - be they European or not. Not allowing representation to nonEuropeans lead to non-representation of Europeans. ${ }^{18}$ We will look into a nonEuropean case study! Saudi-Arabia and the Wahhabi definition of Islam provide us with a case at hand beyond the simple of fact of Saudi (and allied) aircrafts are bombing non-Europeans as European and US aircrafts did before.

\section{Wahhabism \& Saudi-Arabia}

Turning to religion, we may see another non-representative representation ${ }^{19}$ being part of representation liberal democracy style. A brief sketch what the religious variety in Saudi Arabia means in Saudi Arabia, at an Arabic level and a global level may be helpful. To begin with, we have stated that there are some limitations to a thorough understanding of the transformations taking place in Islamic communities since the sixteenth century by many observers. We may, however, discern some trends that are characteristic for this period ${ }^{20}$ :

1) Islam has to become a religion, turning away from the fluid, complex, and even contradictory ways to interact with the revelation starting from a pre-text (or some pre-texts), be it theological, philosophical, natural philosophy, art, music, poetry, mysticism etc.;

2) this new religion of Islam has to produce claims of validity or truth projects for the social order of the communities competing with other - older - claims. Esp., the claims have to be understood as the basis for a new complex set of rules for the way of ruling and the way of public behavior;

3) a new political community, i.e., a state, emerges as the basis of this Islam, theology becoming political ${ }^{21}$

17 This will be important for the discussion of the Saudi aerial bombing.

18 When non-Europeans defended themselves successfully again European armies it was worse. E. g., think of the "savage" Mahdi followers in Sudan or the "Mad Mullahs" etc. We can't follow this line of thought.

19 For those who are not able to understand: This is to read as an ironic remark.

20 We refer to Reinhard Schulze, Geschichte der islamischen Welt: Von 1900 bis zur Gegenwart, München: C. H. Beck 2016 and Shahab Ahmad, What is Islam? The Importance of Being Islamic, Princeton, NJ / Oxford: Princeton University Press 2016.

21 For interesting reflections on the relations of religion, theology, and the political see Wolfgang Palaver et al. (eds.), Politische Philosophie versus Politische Theologie? Die 
4) a new understanding of the Islamic sources, distancing itself from other traditions regarded as non-religious;

5) general rules of conduct of the individuals are transformed general, binding standards for the community;

6) at least one group or community of Muslims agrees on these standards;

7) this group/community (jama'a $)^{22}$ raises a claim to rule.

This community pretends to be the direct expression of the will of the Muslim community at large or the unmediated realization of God's will on earth. We might say these movements (including Wahhabism) claim a representation without representing anyone but God.

The transformation movement at the Arabian Peninsula that became the dominant religious tendency is usually called Wahhabism. This tendency emerged in the 18th century as part of the larger movements of transformation in the Islamic world. ${ }^{23}$ For us it may be interesting that the adherents of Wahhabism called themselves, e. g., "professors of the oneness of God" (muwahhidun) or just "Muslims" (muslimun) claiming as such to be the true incarnation of Islam and Muslims negating the possibility of mediating authorities between god and the believers, that existed before and still continued to exist. And it destroyed the seeds of an emerging representative process, e.g., a modernized, reformed Islam, be it modernist or traditionalist, in the wake of modern forms of globalization. So we talk - based on historical evidence - of a non-representational form of Islam eradicating every of pre-modern intermediation and representation.

This non-representational Islam is discernible if we look into the basic theological tenets of the exclusivist forms of Islam like Wahhabism. Starting with tawhid, the profession that there is only one god, a second tenet is the interdiction of adding an object of worship to God. A third one is the need to dissociate from anybody who is not accepted as a true Muslim and the association who are not true Muslims. A very elaborate theology of hell is enforcing these attitudes. Strict condemnation of any other ways of being Muslim is another aspect of this theology of exclusivism claiming to be the only way of relating to god islamically. ${ }^{24}$

Frage der Gewalt im Spannungsfeld von Politik und Religion, Innsbruck: Innsbruck University Press 2011.

22 See for the idea of community Rüdiger Lohlker, "Jamā'a vs. Mulk: Communitycentered and ruler-centered visions of the Islamic community", in: Eirik Hovden et al. (eds.), Meanings of Community across Medieval Eurasia, Leiden/Boston: Brill 2016, pp. 78-96.

23 Rüdiger Lohlker, Islam: Eine Ideengeschichte, Wien: facultas/wuv 2008, pp. 173 seqq.

24 For exclusivism as a concept for the phenomena discussed here see Rüdiger Lohlker, "Excluding the Other: Wahhabism, Salafism, Jihadism, and Political Islam", in: Totalitarismus und Demokratie 14ii (2017), pp. 265-289. 
It is well known Wahhabi Islam depends on the support of the Saudi ruling family and vice versa, the rulers turned the servants of Islam being entitled to use religion for their own ends. This connects the Saudi-Wahhabi polity to the globalized petrol-economy since the 1930 s and as such being part of the societies that became the epitome of liberal democracies at first economically. From this starting point, the economic influence of Saudi-Arabia crept into world economy, esp., in the so-called liberal democracies and after the 1970s. Seen, full of resentment by Western media, e.g., in the figure of the 'Arab sheik' attacking the resources of the Western world during the so-called oil crisis 1973. The intricate relations of Saudi (and other Arab) investments and 'Western' interests would deserve a thorough discussion that cannot be done here. But for our purpose, we may say - without turning to Marxist arguments - these economic dimensions are another "subrepresentational" aspect of global Saudi influence.

Since the 1960s another process begins. Feeling threatened by the mounting influence of Nasserist Arab Socialism (and other varieties of Arab nationalism), the Saudi government established a body of scholars of Wahhabi scholars and non-Wahhabi scholars, the Islamic World League. ${ }^{25}$ The main function was the propaganda for the true Islam, i.e., Wahhabi Islam, at a global level. This global propaganda effort deeply transformed the structure - material and mental - of the global Islamic community, the umma, into an Islamic modernity influenced by the structures of Wahhabi (and Salafi Islam, partly an offspring of Wahhabism). The umma is conceived as a global nation-state of Islam, the leading power of contemporary Islam - in their perceptions - the Saudis/Wahhabis, have the right to speak for - another form of non-representational representation legitimated by power and economical means. This is furthered by the establishment of the Islamic University of Medina, giving students worldwide an opportunity to study Islam Wahhabi style. The alumni of this university form another network spreading the Wahhabi and Salafi brand of Islam. ${ }^{26}$ Another element is sending missionaries everywhere, promoting mosques and Islamic centers (often funded by the Saudi dominated Islamic World League), producing and disseminating copies of the Quran, activities aiming at the acquisition of symbolic or religious capital. These activities are truly globalized using every means of communication available. $^{27}$

We will not talk about the involvement of Saudi-Arabian nationals and of Saudi funding into the Jihadi movements worldwide. But there is another inter-

25 Rüdiger Lohlker, Die Salafisten: Der Aufstand der Frommen, Saudi-Arabien und der Islam, München: C. H. Beck 2017, pp. 106-108.

26 See Lohlker, Die Salafisten, pp. 110-111.

27 See the chapters on Saudi Arabia in Lohlker, Die Salafisten. A treasure trove of information on the globalized aspect of Wahhabism (and Saudi Arabia) is to be found at "Saudi Cables". Internet source: The Saudi Cables. Cables and other documents from the Kingdom of Saudi Arabia Ministry of Foreign Affairs. 
esting fact. Jihadis are threatening, e. g., the voters in US elections ${ }^{28}$, do not accept any distinction between governments, security forces, and civilians, all of them legitimate targets of Jihadi attacks. Structurally speaking this can be seen as a parallel to the justification for attacks of civilians in wartime by nation states. Terrorists claiming statehood on another level, too, and doing another step of integration into the globalized world. In this respect acting very similar to their Saudi-Wahhabi relatives, threatening the very act of representation.

Turning to the example of the war in Yemen this gets another meaning: it is a punitive war against rebels, i. e., criminal violating the hallowed principle of Saudi dominance at the Arab Peninsula and, coming back to religion, challenging another principle: the subordinate status of Shiite people in the same region, since the sole representation of Islam accepted is the representation by the true Muslims, i.e., Wahhabis. People not accepting are judged as being criminals, to be eradicated from earth not to be represented by any/body. As to the Shiites this can be easily detected by the sayings of Wahhabi scholars supporting the alternative for Shiites: conversion to Wahhabi Islam or complete eradication. ${ }^{29}$ This does not allow for any representation at all, since no sovereign/judge/mediator for Yemeni Shiites is accepted.

Any representation disappearing in the havoc of a totalized warfare has farreaching effects: a non-representative representation of being - true - Muslim overtly declares its willingness to act as a terrorist entity following the modern policy of the colonial police bombings. And - as a logical consequence - this way of great/small warfare is supported by many liberal democracies that are 'liberal' at home. Another element of this kind of cohabitation is the conspicuous way Iran - as the important regional competitor of Saudi Arabia - is described as a global evil or criminal not to be treated as a national state like others linking the interest of global powers to regional powers to a totalized religious system cutting out any method of mediation.

This can be read "as a result of internal tensions in representation's organizational structure, what Deleuze calls the 'catastrophes' [...] of representation."”30

It is evident why it seems legitimate to describe Saudi Arabia as "an ISIS that has made it" ${ }^{31}$, as Kamal Daoud, the Algerian writer, puts it, using the same terrorist practice and denial of the right to exist for anybody who does not follow the same theology of violence as jihadists do.

If we think of representation as the only face of liberal democracy, we should be reminded that there is another face, less attractive but part of the same head becoming visible in the age of globalization. Globalization, we have been told,

28 There are many files online illustrating these threats.

29 Lohlker, Die Salafisten, p. 131.

30 Somers-Hall, Hegel, Deleuze. p. 35.

31 Kamel Daoud, "Saudi Arabia, an ISIS That Has Made It", in: The New York Times, November $20^{\text {th }}, 2015$. 
includes a fading away of nation-states and the emergence of a 'global culture'32 but the exemplum of the aerial war tells another story:

"At the same time, however, strategic bombing already looks beyond the national horizon of war. The essential weakness of the concept of national war is the fact that it tends to take the nation as a given unity. Sovereignty had formerly been conceptualized as emanating from the person of the monarch: the further removed from the monarch's vision, the more sovereignty became diluted. This is why it has been said that 'real' sovereignty was invented by the emerging national state during the time of the French Revolution. This 'real' sovereignty - popular sovereignty - replaces the absent vision of the monarch with the omnipresent vision of the panopticon. The nation as a whole becomes the realm of sovereignty. Nation, state, and sovereignty are the same, but this sovereign national state is conceived on the model of monarchical sovereignty, as a unity. But at the same time, it is evident that bombing strategies allow the inevitable fragility of this unity: hence strategic bombing relies on the idea that it can be undone; centres of political decisionmaking can be 'beheaded,' and workers can be induced to rebel against their governments. If the state apparatuses no longer function and become unable to protect citizens from being targeted, national unity will fade away into anarchy and civil war. In other words, the nation is unstable in itself, and beneath national unity lurks the threat of civil war."33

That a nation-state is unstable in itself is demonstrated by the Saudi-led coalition and its US- and other supporters destroying the Yemeni nation state as a moral lesson for everybody aiming at a dissolution of the nation-state of KSA and creating a situation a civil war may occur in Saudi Arabia itself.

But there is more to it: Looking beyond the horizon of the national states from another angle we may see states cum movements like Saudi-Arabia, we see a truly globalized world-view transcending any national state and privileging a religious framework for understanding the global system, claiming to be dominated by a kind of true Islam embodied in the KSA with a global outreach.

This political aspect is strengthened by the support of an economical and politico-military power by other global powers, ignoring the religio-theological realm established by the Wahhabi-Salafi influence as a collateral damage that is justified by the overwhelming gains to be earned, be it economic ${ }^{34}$ or military/ political.

32 For a critical view see Subhabrata Bobby Banerjee / Stephen Linstead, "Globalization, Multiculturalism and other Fictions: Colonialism for the New Millenium?", in: Organization 8iv (2001), pp. 683-722.

33 Hippler, Bombing, pp. 258 seq.

34 For insights into the Saudi economy see Mohamed A. Ramady, The Saudi Arabian Economy: Policies, Achievements, and Challenges, New York et al.: Springer $2010^{2}$ and Tim Niblock / Monica Malik, The Political Economy of Saudi Arabia, London / New York: Routledge 2007. 
This may best be illustrated by the meeting on February 14, 1945 on board of an American warship of President Franklin D. Roosevelt and King Abdul Aziz ibn Saud shaping the future of the MENA region. ${ }^{35}$ The US-president accepting the important role of the Saudi ruling family and implicitly the truth claims of Wahhabi clerics for the Arab and Islamic world; the king supporting the role of the USA in the region.

The justification to be - not to represent! - true Islam may be based on spurious grounds looking at the globalized actions of the offspring of Wahhabi-Salafism I would like to call Jihadism. It is a competition between two varieties of exclusivist Islam both claiming to be the legitimate heirs of the Wahhabi movement emerging in the eighteenth century. The Jihadi one focussing on the use of violence as its main characteristic, the Saudi one drawing legitimacy from its relation to the KSA and its rulers. Both of them are acting and thinking globalized. The Jihadi one fighting a global war, the Saudi one building institutional and investment networks; sometimes both forms of exclusivism are overlapping. In a wider comparative view we may be reminded of another phenomenon of illegal activities, global organized crime, ignored in the usual way of conceptualizing representation and globalization often connected to Jihadism. ${ }^{36}$ That is another line we cannot follow here.

\section{Conclusion}

To summarize the picture of globalized representation/non-representation, we may say liberal democracies and its ideas of representation are not as universal as they try to project it. On a theoretical level it is easy to demonstrate that the claims of representation are not successful. Theoretically speaking, looking into the hidden face of liberal demonstration reveals that this conceptualization of representation means the permanent exclusion of 'non-civilized', 'non-represented' sectors of humanity.

There are other sectors of contemporary world society that are supported by states claiming 'civilized' representation. The case study discussed here is SaudiArabia, a paradigm of a unique view of Islam cutting off any link to the variantology of Islamic history, a possible source for constructing another form of

35 See Thomas W. Lippman, “The Day FDR met Saudi Arabia's Ibn Sa'ud”, in: The Link 38ii (2005) for a vivid account of this meeting.

36 See one of the few studies available Aisha Ahmad, Jihad \& Co.: Black Markets and Islamist Power, Oxford et al.: Oxford University Press 2017. On the need for further research in this field see Rüdiger Lohlker / Amr El Hadad / Philipp Holtmann / Nico Prucha: "Transnationale Welten", in: Janusz Biene et al. (ed.): Salafismus und Dschihadismus in Deutschland: Ursachen, Dynamiken, Handlungsempfehlungen, Frankfurt a. M.: Campus 2016, pp. 199-232. 
representation than the dominant one. Thus the representation conventional style is built on a system of non-representation claiming the representation of nondifference. This affects all aspects of representation - Western style.

This is the true meaning and the hidden face of the admiration of dictators who seem to guarantee or have guaranteed order and security - as long as they comply with the interests of the liberal democracies. Fitting well into the construction of and the judgement on the nature of the Other.

Reflecting this difference by using ideas of Deleuze helps to rethink conventional ideas of representation and deconstructing the hierarchical structure inherent in these ideas of representation.

\section{References}

Ahmad, Aisha: Jihad \& Co.: Black Markets and Islamist Power, Oxford et al., Oxford University Press 2017.

Ahmad, Shahab: What is Islam? The Importance of Being Islamic, Princeton, NJ / Oxford, Princeton University Press 2016.

Banerjee, Subhabrata Bobby / Linstead, Stephen: "Globalization, Multiculturalism and other Fictions: Colonialism for the New Millenium?”, in: Organization 8iv (2001), pp. 683-722.

Callwell, Charles E.: Small Wars: Their Principles and Practice, London, H.M.S.O $1906^{3}$.

Deleuze, Gilles: Expressionism in Philosophy: Spinoza, New York: Zone Books 1990.

Dittrich, Christoph: Weder Herr noch Knecht: Deleuzes Spinoza-Lektüren, Wien/Berlin, Turia und Kant 2012.

Ferris, Jesse: Nasser's Gamble: How the Intervention Caused the Six-Day-War and the Decline of Egyptian Power, Princeton, NJ, Princeton University Press 2013.

Hippler, Thomas: Bombing the People: Giulio Douhet and the Foundation of Air Power Strategy, 1884-1939, Cambridge et al., Cambridge University Press 2013.

Lohlker, Rüdiger: Die Salafisten: Der Aufstand der Frommen, Saudi-Arabien und der Islam, München, C. H. Beck 2017.

Lohlker, Rüdiger: "Excluding the Other: Wahhabism, Salafism, Jihadism, and Political Islam", in: Totalitarismus und Demokratie 14ii (2017), pp. 265-289.

Lohlker, Rüdiger: Islam: Eine Ideengeschichte, Wien: facultas/wuv 2008.

Lohlker, Rüdiger: "Jamā’a vs. Mulk: Community-centered and ruler-centered visions of the Islamic community", in: Eirik Hovden et al. (eds.), Meanings of Community across Medieval Eurasia, Leiden / Boston, Brill 2016, pp. 78-96.

Lohlker, Rüdiger / El Hadad, Amr / Holtmann, Philipp / Prucha, Nico: “Transnationale Welten”, in: Janusz Biene et al. (ed.): Salafismus und Dschihadismus in Deutschland: Ursachen, Dynamiken, Handlungsempfehlungen, Frankfurt a. M.: Campus 2016, pp. 199-232.

Niblock, Tim / Malik, Monica: The Political Economy of Saudi Arabia, London / New York, Routledge 2007. 
Palaver, Wolfgang et al. (eds.): Politische Philosophie versus Politische Theologie? Die Frage der Gewalt im Spannungsfeld von Politik und Religion, Innsbruck, Innsbruck University Press 2011.

Ramady, Mohamed A.: The Saudi Arabian Economy: Policies, Achievements, and Challenges, New York et al., Springer $2010^{2}$.

Raschke, Carl: Force of God: Political Theology and the Crisis of Liberal Democracy, New York / Chichester, Columbia University Press 2015.

Schulze, Reinhard: Geschichte der islamischen Welt: Von 1900 bis zur Gegenwart, München, C. H. Beck 2016.

Somers-Hall, Henry: Hegel, Deleuze, and the Critique of Representation. Dialectics of Negation and Difference, Albany, NY, SUNY Press 2012.

Terrill, W. Andrew: "The Chemical Warfare Legacy of the Yemen War", in: Comparative Strategy 10ii (1991).

\section{Internet Sources}

Daoud, Kamel: "Saudi Arabia, an ISIS That Has Made It", in: The New York Times, November $20^{\text {th }}$, 2015, available here: https://www.nytimes.com/2015/11/21/opinion/ saudi-arabia-an-isis-that-has-made-it.html [September $9^{\text {th }}, 2018$ ].

Darwich, May: "Machtprestige als Motiv des saudischen Krieges im Jemen", in: GIGA focus nahost 6/2015, pp. 1-8, available here: https://www.giga-hamburg.de/de/pub lication/machtprestige-als-motiv-des-saudischen-krieges-im-jemen [September $27^{\text {th }}$, 2018].

Ellyatt, Holly: Saudi Arabia and Iran's Feud has entered a new 'unpredictable' phase, available here: https://www.cnbc.com/2017/12/20/saudi-arabia-and-irans-conflict-inyemen.html [December 28 ${ }^{\text {th }}, 2017$ ].

Laub, Zachary: Yemen in Crisis, April 19, 2016, availabel here: https://www.cfr.org/ backgrounder/yemen-crisis [December 27 ${ }^{\text {th }}, 2017$ ].

Lippman, Thomas W.: “The Day FDR met Saudi Arabia's Ibn Sa'ud”, in: The Link 38ii (2005), available here: https://www.ouramazingworld.org/uploads/4/3/8/6/43860587/ vol38_issue2_2005.pdf [December $\left.28^{\text {th }}, 2017\right]$.

The Saudi Cables. Cables and other documents from the Kingdom of Saudi Arabia Ministry of Foreign Affairs, available here: https://wikileaks.org/saudi-cables/ [December $\left.30^{\text {th }}, 2017\right]$.

Rüdiger Lohlker, Oriental Institute, Faculty for Philological and Cultural Studies, University of Vienna, Austria, e-mail: ruediger.lohlker@univie.ac.at

Citation: Lohlker, Rüdiger: "Representation with/out Representation: Saudia Arabia as a Hidden Face of Globalization", in: Appel, Kurt / Raschke, Carl (eds.): The Crisis of Representation (J-RaT 2018 / 2) pp. 110-123.

Datum der Publikation: 21.01.2019 